\title{
Physiology of Fruit Development
}

\author{
Bhaskarjyoti Sarma $^{1 *}$, Kaushik Das ${ }^{2}$ and Sarat Sekhar Bora ${ }^{3}$ \\ ${ }^{1}$ Department of Horticulture, Sarat Chandra Sinha College of Agriculture, Dhubri, India \\ ${ }^{2}$ Department of Crop Physiology, College of Agriculture, Jorhat, India \\ 3 (Agro-meteorology), KVK, Udalguri, Assam Agricultural University, \\ Jorhat-785013 (Assam), India \\ *Corresponding author
}

\section{Ke y words \\ Mature ovary four phases parthenocarpy chlorophyllase enzyme \\ Article Info \\ Accepted: \\ 15 May 2020 \\ Available Online: \\ 10 June 2020}

\section{A B S T R A C T}

\section{Introduction}

Fruit development is comprised of a series of complex physiological, biochemical and genetic processes. The numbers of research papers on basic questions concerning the growth and development of fruits are meagre in comparison with those on other aspects of plant growth. Physiologists are naturally reluctant to work on a subject for which the
A fruit can be defined as a mature ovary. Fruit development can generally be considered to occur in four phases, viz., fruit set phase, rapid cell division, cell enlargement, and maturation and ripening. Generally, fruit development follows a sigmoid growth. But, in case of stone fruits and some other fruits double sigmoid growth curve is noticed. Fruit set normally requires the full completion of fertilization, although in some plants fertilization can be bypassed leading to the formation of a seedless fruit, a process referred to as parthenocarpy. Ruan et al., (2012) put forwarded sugar signalling model and multihormonal model, which regulate the fruit set process. After fruit set, cell division and cell enlargement phases are regulated by hormones and the hormonal environments are again governed by seeds. It was found that cell division phase is more critical than subsequent cell expansion in determining final fruit size. Fruit maturity is a developmental point where the fruit has reached the competence to ripen but has yet to start the ripening process. During maturation, changes in phenolic, anthocyanin and flavonoid compounds were noticed ( $\mathrm{Li}$ et al., 2019). Ripening, a complex process involving changes to the metabolic and physiological traits of a fruit starts just after maturation. Ethylene is the major hormone, which regulates most of the events occur during ripening. Chlorophyll degradation is a significant event during fruit ripening, which is mediated by chlorophyllase enzyme. Accumulation of carotenoids at different development stages was co-ordinately controlled by differential expression of biosynthetic pathway genes especially DkPSY, DkZDS, DkLCYb and DkBCH (Qi et al., 2019). Chea et al., (2019) noticed activities of cell wall modifying enzymes, viz., Polygalacturonase, $\alpha$-Arabinofuranosidase, $\beta$-galactosidase, $\alpha$-Mannosidase, $\beta$ Xylosidase and Endo-1,4- $\beta$-xylanase, which modified the cell wall components of blueberry to make the fruit ysis of starch to sugar is a characteristic feature of fruit ripening. During maturation and ripening, the the aroma compound present in all the biotypes of pitanga fruit (Ramalho et al., 2019). During entire developmental process of a fruit, calcium plays a pivotal role. Lots of variations were noticed in the fruit development of various plant species. So, further studies are required in this line. 


\section{Fruit}

The word "fruit" derives from the Latin word "fructus" meaning to enjoy, produce. A fruit is the product of determinate growth from an angiospermous flower or inflorescence. From botanical standpoint a fruit can be defined as a matured ovary. The Oxford English Dictionary defines fruit as "the edible product of a plant or tree, consisting of the seed and its envelope, especially the latter when juicy and pulpy".

Nitsch (1952) recognized that the botanist's definition did not always meet the layman's concept of a fruit and emphasized that the unifying factor was physiological and, he therefore defined fruits as "the tissues which support the ovules and whose development is dependent on the events occurring in these ovules". Fruit evolved as vehicles for production and dispersal of seeds.

Humans then imposed further selection pressures to develop products for our use. Such development has accelerated over the past century. The concept of a fruit as a sweet and fleshy object for eating is really quite recent in evolutionary terms.

\section{Fruit growth dynamics}

Fruit can increase in mass or volume by 100 fold or more from fertilisation to maturity, and such changes commonly follow a sigmoid curve (Fig. 1). Interpretation of such growth curves is complex because a single variable (mass, length, volume) is commonly applied to an object that contains several organs and different tissue types, each developing at their own rate and in accordance with their own programme. Moreover, at a cellular level, comparative levels of division and expansion change with ontogeny, while shifts in airspace percentage also play a part in volume increases (Brummell, 2013).
In fruits like late maturing peaches and other stone fruits double sigmoid growth curve is observed (Fig. 1). It is primarily just an outcome of the development patterns of fruit over daily (or smaller) time steps to their size or development state at the beginning of a time state. Here, growth takes place in three distinct stages. In stage I, ovary, nucellus and integuments of the seed grow rapidly, but the embryo and endosperm grow little. In stage II, embryo and endosperm grow rapidly, but ovary does not increase much in size. Again, at stage III, a surge of ovary growth begins and continues to fruit ripening.

\section{Fruit development}

Fruit development can be divided into four major phases, viz., fruit set, rapid cell division, cell enlargement, and maturation and ripening (Fig. 2).

\section{Fruit set}

Fruit set is the transition from non-growing ovaries to rapidly developing fruits. It normally requires the full completion of fertilization, although in some plants fertilization can be bypassed leading to the formation of a seedless fruit, a process referred to as parthenocarpy (Joldersma and Liu, 2018).

\section{Models for regulating fruit set}

Ruan et al., (2012) put forwarded sugar signalling model and multihormonal model, which regulate the fruit set process. In sugar signalling model two sets of conditions are considered (Fig. 3). Under optimal conditions, phloem unloaded sucrose is hydrolyzed by invertase (INV) in ovaries and ovules. The resultant glucose functions as a signal to repress programmed cell death (PCD) genes and to promote cell division, which together lead to seed and fruit set. 
Starch reserve may be remobilized to supplement glucose production, particularly under mild stress conditions. Under severe stress, phloem import of sucrose is blocked, which in turn decreases INV activity. This, together with depletion of starch reserve, reduces glucose levels that activate the PCD pathway and inhibit cell division. Consequently, seed and fruit abort.

In multihormonal model, a set of hormones are responsible for fruit set to occur (Fig. 4). According to this model, pollination and fertilization result in increased levels of both auxin and gibberellins (GA), which triggers fruit growth through stimulation of cell division and expansion.

Auxin can stimulate fruit set either directly or via inducing GA biosynthesis. Each hormone seems to play a specific role given that auxin application results in a high number of pericarp cells, whereas GA treatment results in fewer but larger pericarp cells.

Natural fruit set seems to require both hormones given that only parthenocarpic fruits induced by concomitant auxin and GA treatment are similar to pollination- induced seeded fruits.

Putative involvement of ethylene and abscisic acid (ABA) in regulating fruit formation has been mainly suggested by transcriptomic studies. In particular, during the transition from anthesis to post-anthesis, ethylenerelated genes, along with those related to auxin, account for most of the changes among all phytohormone-related genes, thus indicating that ethylene must play an active, but yet not understood, role in fruit set.

Exogenous application of cytokinin can induce parthenocarpic fruit yet the underlying model of action remains unknown (Ruan et al., 2012).
Genes involved in fruit set and development

There are several genes involved in the process of fruit set and subsequent development. More studies have been done in this regard in the crop Arabidopsis. Arabidopsis fruits develop from two fused carpels and the specialized capsules called siliquas. The genes involved are:

Fruitfull (FUL): proper valve development and represses SHP 1/2 (Ferrándiz et al., 2000)

Shatterproof 1/2 (SHP1/2): valve margin development (Liljegren et al., 2000)

Replumless (RPL): replum development and represses SHP1/2 (Roeder et al., 2003)

SHP1/2 activate Indehiscent (IND) and ALCATRAZ (ALC), both necessary for the differentiation of the dehiscence zone between the valves and replum (Girin et al., 2011).

\section{Fruit cell division and cell expansion}

Fruit growth through cell division and expansion is controlled by hormones (Mc Atee et al., 2013). Differential hormone concentration occur in seed and surrounding tissue with developing seed influencing its environment. Multiple studies have shown that increases in auxin, cytokinin, gibberellin, and brassinosteroid at fruit set, and an involvement of auxin, gibberellin, and brassinosteroid at fruit growth. For fruit maturation there is an inhibition of auxin transport from the seed and increase in ABA. This triggers the ripening/senescence programme which leads to an increase in ABA and/or ethylene biosynthesis and response in the surrounding tissue (Fig. 5). Division of fruit cell is critical for determining the final size of the fruit. Zhang et al., (2006) noticed significant differences in cell number at harvest between different 
cultivars of Pyrus pyrifolia and no differences were observed at pollination (Fig. 6). Despite complexities of fruit growth and development, there are some overall consistencies in patterns of cell division and enlargement, as well as tissue differentiation and fruit enlargement (Fig. 7). During the first 1-4 weeks, flesh volume increases rapidly and embryo volume remains small. Growth at this time is mainly the result of cell division (Brummell, 2013).

In kiwifruit all tissues of the mature fruit (exocarp, outer and inner pericarp and central core) are already discernable in the ovary before anthesis and pollination. Each layer grows to a different extent and at different rates, so that the relative contribution of each to the total fruit volume varies with time (Fig. 8). Cell division ceases first in the exocarp and last in the innermost regions of the central core (Brummell, 2013).

\section{Correlation between seed and fruit development}

A positive correlation between the number of seeds in the fruit and final fruit size is noticed (Fig. 9). Seeds serve as source of hormones for cell division and cell division phase is more critical than subsequent cell expansion in determining final fruit size. Fruit size in Braeburn apple depends closely on the number of viable seeds per fruit (up to a normal maximum of 10 per fruit), emphasising the strong influence that seed development has on fruit growth (Brummell, 2013).

\section{Fruit maturation}

Fruit maturity is a developmental point where the fruit has reached the competence to ripen, but has yet to start the ripening process. Several changes were noticed by $\mathrm{Li}$ et al., (2019) in maturing blueberry fruit. They considered five stages of fruit development, viz., pad, cup, green, pink and blue. During maturation, fruit gradually increased in size. In green/pink, the width increased by 29.77 per cent, and height increased by 35.93 per cent, while, in pink/blue, width increased by 11.80 per cent and height increased by 11.13 per cent.

The content of total phenolics dropped by 53.11 per cent in pink/green, but soared by 91.70 per cent in blue/pink (Fig. 10 B1). Five kinds of phenolic acids were determined viz., gallic acid, ellagic acid, chlorogenic acid, caffeic acid, and ferulic acid (Fig. 10 B2). Of them, chlorogenic acid (average of 47.23) and ellagic acid (29.79) were predominant during the whole maturation, while gallic acid (0.44), caffeic acid (0.32), and ferulic acid (0.39) were at relatively low content. All the phenolic acids showed a successive decrease in content during fruit maturation ( $\mathrm{Li}$ et al., 2019).

Five kinds of flavonoids were determined i.e. epicatechin, catechin, quercetin, rutin, and myricetin (Fig. 10 B3). Of them, epicatechin (78.97) and catechin (45.05) were predominant during the whole maturation, while rutin (8.09), quercetin (7.31) and myricetin (1.15) were at relatively low contents (Li et al., 2019). The three kinds of flavonoids, epicatechin, catechin, and rutin, also showed a successive decrease in content while quercetin and myricetin showed a successive increase in content during fruit maturation. Li at al. (2019) also observed that the content of anthocyanins increased by 182.50 per cent in pink/green, and soared by 2684 per cent in pink/blue (Fig. 10 B1).

Six kinds of anthocyanins were measured viz., delphinidin-3-glucoside, delphinidin-3galactoside, petunidin-3-glucoside, petunidin3-galactoside, malvidin-3-glucoside, and malvidin-3-galactoside (Fig. 10 B4). Among 
them, delphinidin-3-galactoside was the most abundant (496), followed by petunidin-3glucoside (337), malvidin-3-glucoside (266), while delphinidin-3-glucoside was the lowest (81.6), followed by malvidin-3-galactoside (136). All the anthocyanins constantly increased in content throughout the whole fruit maturation.

\section{Ripening}

Ripening is a complex process involving changes to the metabolic and physiological traits of a fruit. Several major changes take place as fruits ripen, and taken collectively they characterise ripening processes. They include:

\section{Change in colour.}

Flesh softening and textural change.

Changes in carbohydrate composition, resulting in sugar accumulation and increased sweetness.

Accumulation of organic acids with associated development of flavour.

Formation of aroma volatiles.

Historically fruit have been categorised into two classes of behaviour with respect to ethylene physiology and respiratory pattern. In the first type, as fruit progress towards edibility the respiratory rate increases followed by a decline as fruit senesce. This is known as the climacteric rise. Pear, banana and avocado show an especially strong respiratory rise. Ethylene production also increases sharply to a maximum at this time, and then declines before fruit rots intervene and lead to a renewed output.

The major rise in ethylene production may take place before, just after or close to the respiratory peak. Such fruit are classed as 'climacteric', with apple, avocado, banana, fig, mango, papaya, passionfruit, pear and tomato being classic examples. As with the respiratory rise, the levels of ethylene produced vary widely between species. Climacteric fruit ripen after harvest, and need not remain on the tree or vine. A second category of fruit, exemplified by blueberry, cherry, citrus, cucumber, grape, pineapple and strawberry do not show such sharp changes. Respiration rate either remains almost unchanged or shows a steady decline until senescence intervenes, with little or no increase in ethylene production; these are called 'non-climacteric' fruit, and fruit ripen only if they remain attached to the parent plant.

\section{Ethylene biosynthesis}

Ethylene biosynthesis (Fig. 11) is the key event of ripening. Ethylene production is closely associated with fruit ripening in many species, and is the plant hormone that regulates and coordinates the different aspects of the ripening process; colour development, aroma production and texture are all under the control of ethylene.

Ripening phenomenon of fruit influenced by ethylene is governed by ACS gene expression. Ethylene response factors (ERF) acting on ethylene synthesis to initiate the transition from a system 1 to a system 2 mode of ethylene synthesis regulate the expression of the different ACS genes (Fig. 12). It may also be regulated by very high concentration of IAA (Perotti et al., 2014).

\section{Colour change}

One of the ethylene induced event is colour change. Colour change occur due to degradation and chlorophyll molecules. It may lead to unmasking the already present carotenoid and anthocyanin pigments. At the same time synthesis of carotenoid and anthocyanin pigments is also an influencing factor of colour change. 


\section{Colour change}

One of the ethylene induced event is colour change. Colour changes occur due to degradation and chlorophyll molecules. It may lead to unmasking the already present carotenoid and anthocyanin pigments. At the same time synthesis of carotenoid and anthocyanin pigments is also an influencing factor of colour change.Chlorophyll degradation generally occurs in the following way:

\section{Degradation of chlorophyll due to chlorophyllase enzyme}

\section{Splitting of chlorophyll into phytol chain and porphyrin}

\section{Loss of $\mathrm{Mg}^{++}$ion and conversion of porphyrin into phaeophytin}

\section{Change in tetrapyrrolic chain and it becomes biliviridin}

\section{Oxidation or saturation of double bonds}

Qi et al., (2019) in their study investigated the key carotenoids and their biosynthetic regulation mechanisms in persimmon fruit skin. Carotenoid content and expression patterns of nine carotenogenic genes in skins of 'Jinping', 'Huoguan' and 'Heishi' cultivars were analyzed during fruit development. As skin colour changed, lutein content decreased and $\quad \beta, \beta$-carotenoid $\quad(\beta$-carotene, $\quad \beta$ cryptoxanthin, zeaxanthin), lycopene and $\alpha$ carotene accumulated especially in late development stages (Fig. 13).

At harvest, the major carotenoids in 'Jinping' and 'Heishi' were $\beta$-carotene, while the redcoloured lycopene was predominant in the skin of 'Huoguan'. The minor carotenoids in all three cultivars were free $\beta$-cryptoxanthin, lutein, $\alpha$-carotene and zeaxanthin. Accumulation of carotenoids at different development stages was coordinately controlled by differential expression of biosynthetic pathway genes especially
DkPSY, DkZDS, DkLCYb and DkBCH.

\section{Fruit softening}

Fruit softening in ripening is the result of alterations to various pectin $\&$ hemicellulose polysaccharide wall components, and changes to the bonding between some polymers (Brummell, 2006). In a study in kiwi fruit following changes were noticed which led to fruit softening:

Solubilisation of pectin

The cell wall swells and shows an increased affinity for water

Loss of galactose from pectins (especially of a galactan)

De-esterification of some pectins

Depolymerisation of the hemicellulosic polysaccharide xyloglucan associated with reduction in cell wall strength

Depolymerisation of pectin associated with dissolution of middle lamella and reduced intercellular adhesion 
Chea et al., (2019) studied four stages of 'Bluecrop' highbush blueberry regarding changes in the cell wall composition during ripening. The results are depicted in the Table 1. Several enzymes are responsible for change in the cell wall components leading to fruit softening during ripening. Polygalacturonase (PG) degrades pectin and promotes its solubilization by hydrolyzing the homogalacturonan backbone (Goulao et al., 2007). Pectin methylesterase (PME) hydrolyzes glycosidic bonds of pectic substances (Beigi et al., 2015).

$\alpha$-Arabinofuranosidase \& $\quad \beta$-galactosidase promote pectin solubilization by removing arabinose \& galactose (Paniagua et al., 2016). $\alpha$-Mannosidase cleaves the terminal mannosidic linkage from the mannose rich complex and $\mathrm{N}$-glycans (Liebminger et al., 2009). $\beta$-Xylosidase and endo-1,4- $\beta$-xylanase are hemicellulose modifying enzymes that degrade xylan (Bustamante et al., 2009). Chea et al., (2019) noticed changes in the activities of these enzymes in blueberry (Table 2) leading to soft ripened fruits.

\section{Starch degradation}

Hydrolysis of starch to sugar is a characteristic event of fruit ripening. Starch degrading enzymes are:

$\alpha$ - amylase

$\beta$ - amylase

Phosphorylase

$\alpha-1,6$ - glucosidase

In a study by Xiao et al., (2018), 38 genes encoding starch degradation-related proteins were identified and characterized from banana fruit. Expression analysis revealed that 27 candidate genes were significantly induced during banana fruit ripening, with concomitant conversion of starch-to-sugars. Furthermore, iTRAQ-based proteomics experiments identified 18 starch degradationassociated enzymes bound to the surface of starch granules, of which 10 were markedly up-regulated during ripening. More importantly, a novel bHLH transcription factor, MabHLH6, was identified based on a yeast one-hybrid screening using MaGWD1 promoter as a bait.

Transcript and protein levels of MabHLH6 were also increased during fruit ripening. Electrophoretic mobility shift assays, chromatin immuno precipitation and transient expression experiments confirmed that MabHLH6 activates the promoters of 11 starch degradation-related genes. Collectively, these findings suggest that starch degradation during banana fruit ripening may be attributed to the complex actions of numerous enzymes related to starch breakdown at transcriptional and translational levels, and that MabHLH6 may act as a positive regulator of this process via direct activation of a series of starch degradation-related genes.

\section{Changes in the level of sugars}

During maturation and ripening, sugars accumulate, mainly due to sugar import or from starch degradation. Batista-Silva et al., (2018) studied the sugar accumulation in climacteric tomato and non-climacteric capsicum (Fig. 14). They noticed decreased level of sucrose and increased levels of glucose and fructose along with ripening in both tomato and capsicum.

Sugar levels during ripening exhibited a different trend in jujube (Song et al., 2019), which is depicted in Fig. 15. Four stages were considered for the study, viz., green maturity (GM), yellow maturity (YM), half-red maturity (HRM) and red maturity (RM). It was observed that sucrose and total sugar content increased with ripening, while glucose and fructose content decreased. 


\section{Changes in the level of organic acids}

During maturation and ripening, sugars accumulate, whereas organic acids that accumulated in young fruits strongly decrease (Beauvoit et al., 2018).

Citric acid, malic acid and fumaric acid are the major organic acids found in the fruits. In a study Batista-Silva et al., (2018) found that citrate content increases with stages of ripening in both climacteric and nonclimacteric fruits (Fig. 16). However, reduction in fumarate and malate were observed in tomato as well as capsicum.

\section{Changes in aroma compounds}

Development of characteristic fruit aroma is influenced by ethylene. Fruit aroma is determined by a complex mixture of a large number of volatile compounds including alcohols, aldehydes, and esters. During fruit development, especially at ripening, there are many changes of these metabolites caused by their synthesis, transport or degradation (Defilippi et al., 2009).

Ripeness in 'Alphonso' mango was characterized by the de novo appearance of aroma compounds lactones and furanones in the blend of monoterpenes (Pandit et al., 2009). Germacrene $B$ is the aroma compound present in all the biotypes of pitanga fruit (Ramalho et al., 2019).

In Rubus corchorifolius, Yang et al., (2019) observed that total content of free aldehydes, 2-heptanone, alcohols, esters and phenols increases, but free terpenoids decreases with during ripening.

Bound aldehydes, alcohols, terpenoids, esters and phenols gradually decreases during ripening due to the hydrolyses to their free form. Free aroma compounds of ripened red fruits are hexanal, 2-heptanone, ethyl hexanoate, 4-terpineol, geranial and methyleugenol.

\section{Regulation of ripening by calcium}

Plenty of studies have shown that calcium plays an important role in the storage and preservation of fruits. Role of calcium in delaying senesce can be summarized as -

Maintaining the fruit cell wall structure and function

Maintaining the cell membrane structure and function

The effects on fruit respiration and ethylene synthesis

Regulating activities of enzymes and metabolism of substances related to senescence

A model for calcium signalling was developed by Gao et al., (2019). According to the model, exogenous calcium treatment increased the cytosol calcium, which helped to maintain the cell wall structure, rigidity, and integrity (Fig. 17).

This, in turn, greatly maintained fruit firmness and enhanced the activities of anti-aging enzymes, increased the metabolism of substances related to fruit ripening, and reduced fruit respiration and ethylene production.

As a signal ion, $\mathrm{Ca}^{2+}$ participates in hormone synthesis directly, which could affect the fruit ripening process. Most importantly, the $\mathrm{Ca}^{+}$ signal is perceived, decoded, amplified, and relayed by calcium sensors to the downstream targets and triggers specific responses. During signal transduction, calcium sensors, including $\mathrm{CaM} / \mathrm{CML}$ and $\mathrm{CDPK}$, can interact with components in the hormone signal pathway and affect the physiological response. 
Table.1 Cell wall composition of 'Bluecrop' highbush blueberry during ripening

\begin{tabular}{|c|c|c|c|c|c|c|}
\hline \multirow[t]{2}{*}{$\begin{array}{l}\text { Ripening } \\
\text { stage }\end{array}$} & CWM & WSP & ESP & HSP & $\begin{array}{l}\text { Hemi- } \\
\text { cellulose }\end{array}$ & Cellulose \\
\hline & $\left(\mathrm{mg} \mathrm{AIR} \mathrm{g}{ }^{-1} \mathrm{FW}\right)$ & \multicolumn{3}{|c|}{$\left(\mu \mathrm{g}\right.$ GalUA mg ${ }^{-1}$ AIR $)$} & \multicolumn{2}{|c|}{ ( $\mu \mathrm{g}$ Glu $\mathrm{mg}^{-1}$ AIR) } \\
\hline Pale Green & $56.4 \mathrm{a}$ & $20.6 c$ & $5.7 \mathrm{~b}$ & $60.0 \mathrm{a}$ & $25.2 \mathrm{a}$ & $21.2 \mathrm{a}$ \\
\hline $\begin{array}{l}\text { Reddish } \\
\text { Purple }\end{array}$ & $47.2 \mathrm{~b}$ & $89.6 \mathrm{a}$ & $7.9 \mathrm{~b}$ & $18.8 b$ & $17.1 \mathrm{~b}$ & $18.2 \mathrm{a}$ \\
\hline Dark Purple & $30.50 \mathrm{c}$ & $77.6 \mathrm{~b}$ & $7.7 \mathrm{~b}$ & $21.6 b$ & $20.6 b$ & $21.4 \mathrm{a}$ \\
\hline Dark Blue & $31.90 \mathrm{c}$ & $73.8 b$ & $23.1 \mathrm{a}$ & $21.2 b$ & $20.2 b$ & $22.7 a$ \\
\hline
\end{tabular}

N.B. CWM: Cell wall material, WSP: Water soluble pectin, ESP: EDTA-soluble pectin, HSP: HCl-soluble pectin, AIR: Alcohol-insoluble residue, FW: Fresh Weight, GalUA: Galacturonic acid, Glu: Glucose

Table.2 Activities of cell wall modifying enzymes in 'Bluecrop' highbush blueberry during ripening

\begin{tabular}{|c|c|c|c|c|c|c|}
\hline \multirow[t]{2}{*}{$\begin{array}{l}\text { Ripening } \\
\text { stage }\end{array}$} & $\begin{array}{l}\text { Polygala } \\
\text { cturonase }\end{array}$ & $\begin{array}{c}\alpha- \\
\text { Arabinofura } \\
\text { nosidase }\end{array}$ & $\begin{array}{c}\beta- \\
\text { galactosidase }\end{array}$ & $\stackrel{\alpha-}{\text { Mannosidase }}$ & $\begin{array}{c}\beta- \\
\text { Xylosidase }\end{array}$ & \multirow{2}{*}{$\begin{array}{c}\text { Endo-1,4- } \\
\boldsymbol{\beta} \text {-xylanase } \\
(\mu \mathrm{mol} \mathrm{Xyl} \\
\mathrm{h}^{-1} \mathrm{mg}^{-1} \\
\text { protein) }\end{array}$} \\
\hline & $\begin{array}{c}(\mathrm{nmol} \mathrm{GalUA} \\
\mathrm{min}^{-1} \mathrm{mg}^{-1} \\
\text { protein }^{-1}\end{array}$ & \multicolumn{4}{|c|}{ (nmol pNP $\min ^{-1} \mathrm{mg}^{-1}$ protein) } & \\
\hline Pale Green & $70.8 \mathrm{a}$ & $27.1 \mathrm{a}$ & $312.0 \mathrm{a}$ & $9.4 b$ & $247.7 \mathrm{a}$ & $12.6 \mathrm{a}$ \\
\hline $\begin{array}{l}\text { Reddish } \\
\text { Purple }\end{array}$ & $80.7 \mathrm{a}$ & $14.1 b$ & $257.3 \mathrm{a}$ & $12.7 b$ & $246.3 a$ & $10.0 \mathrm{a}$ \\
\hline Dark Purple & $51.1 \mathrm{~b}$ & $11.8 \mathrm{~b}$ & $289.6 a$ & $54.8 \mathrm{a}$ & $213.2 b$ & $15.3 \mathrm{a}$ \\
\hline Dark Blue & $44.2 b$ & $13.5 b$ & $186.6 b$ & $54.0 \mathrm{a}$ & $114.5 \mathrm{c}$ & $15.8 \mathrm{a}$ \\
\hline
\end{tabular}

N.B. GalUA: Galacturonic acid, pNP: p-Nitrophenol, Xyl: Xylose

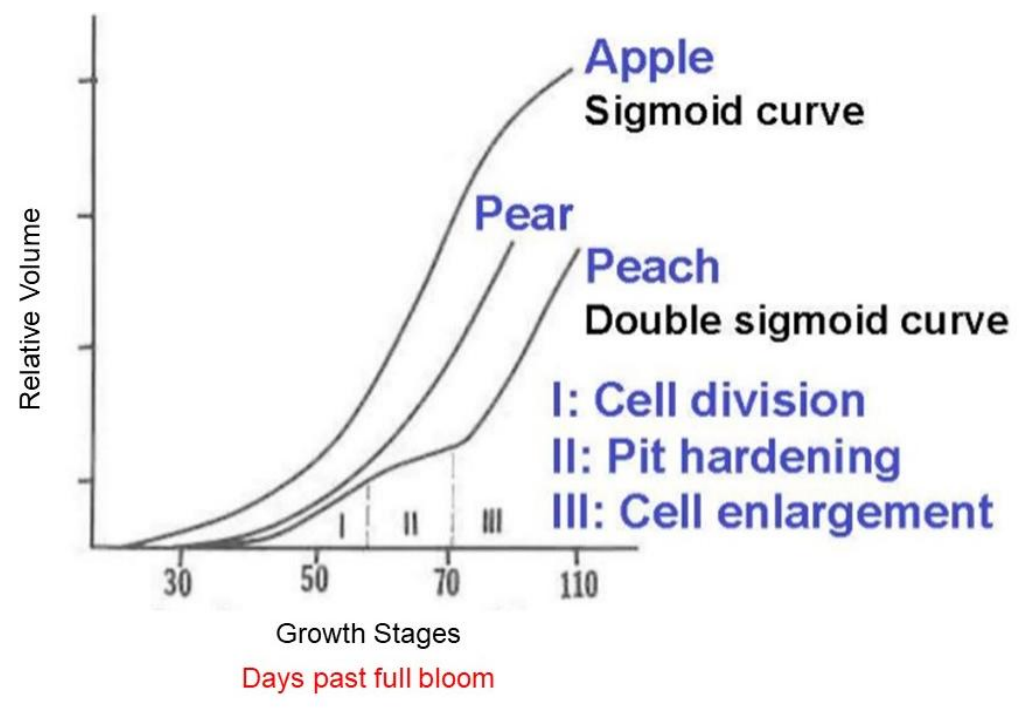

Fig.1 Fruit growth curve 


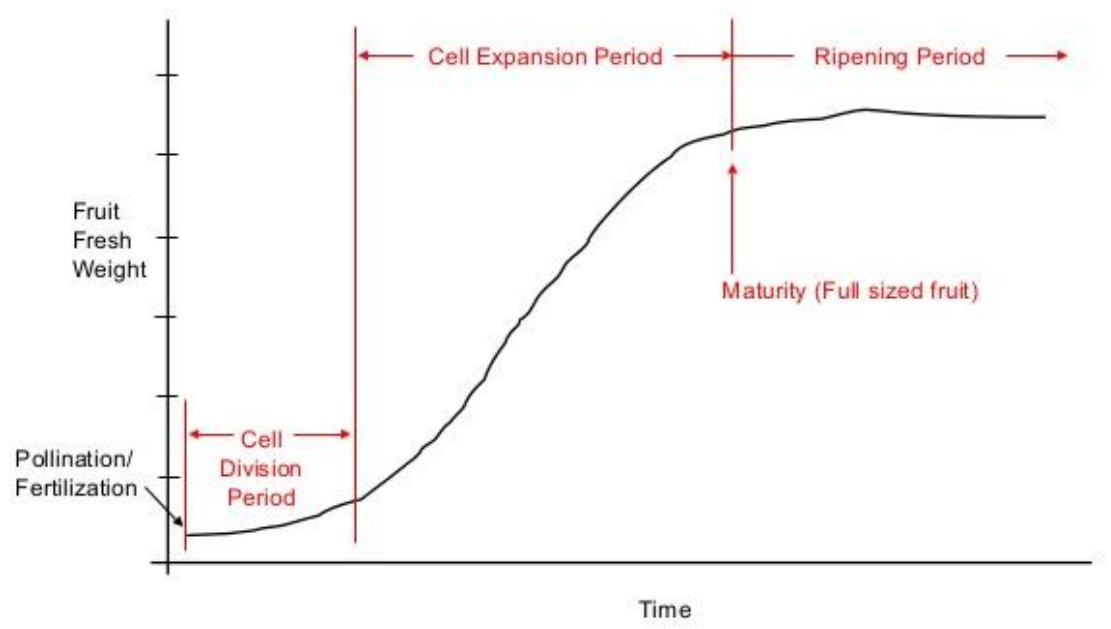

Fig.2 Fruit development pattern

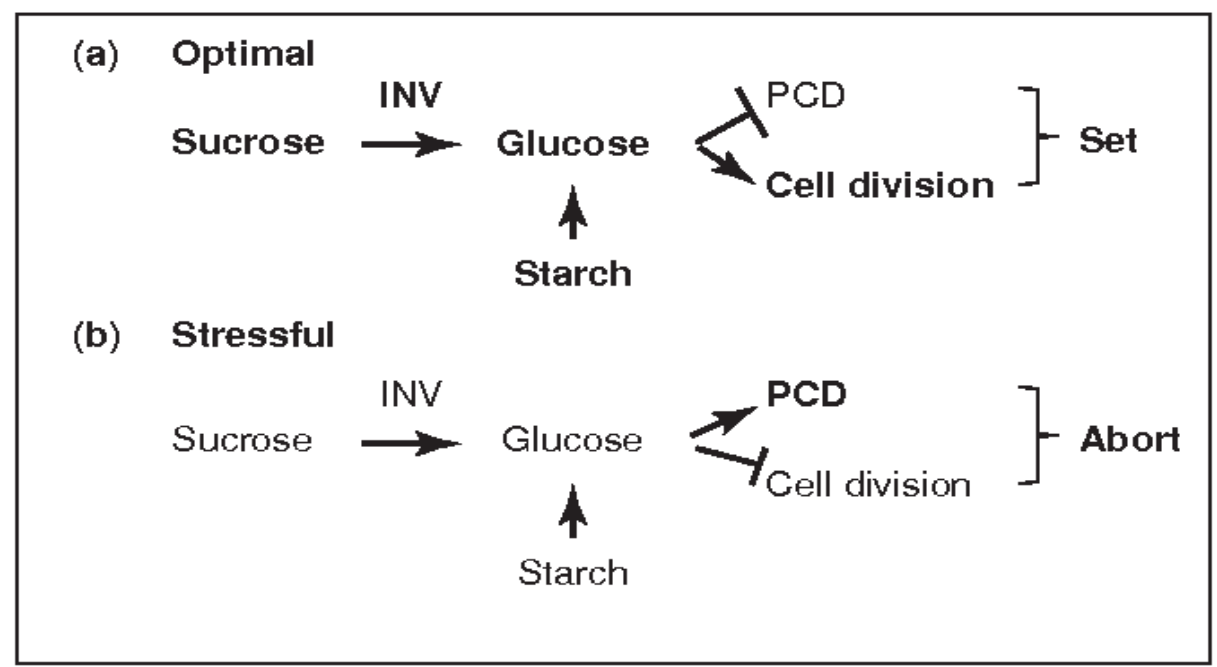

Fig.3 A model for regulation of fruit set through sugar signalling (Ruan et al., 2012)

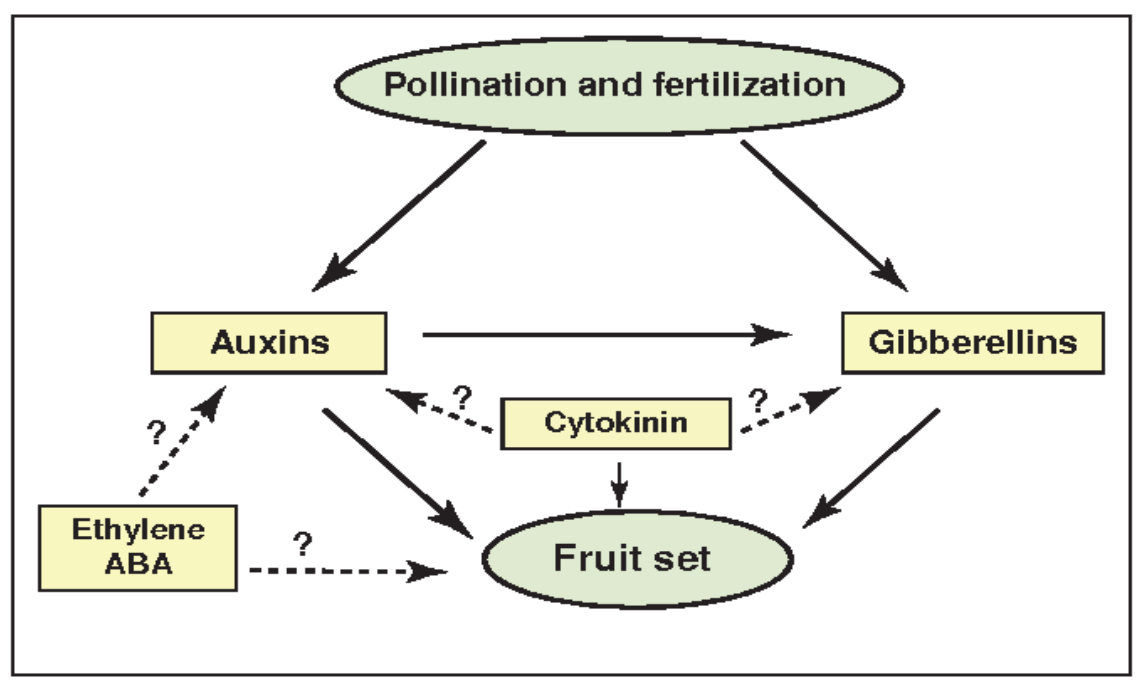

Fig.4 A model for multihormonal regulation of fruit set (Ruan et al., 2012) 
A

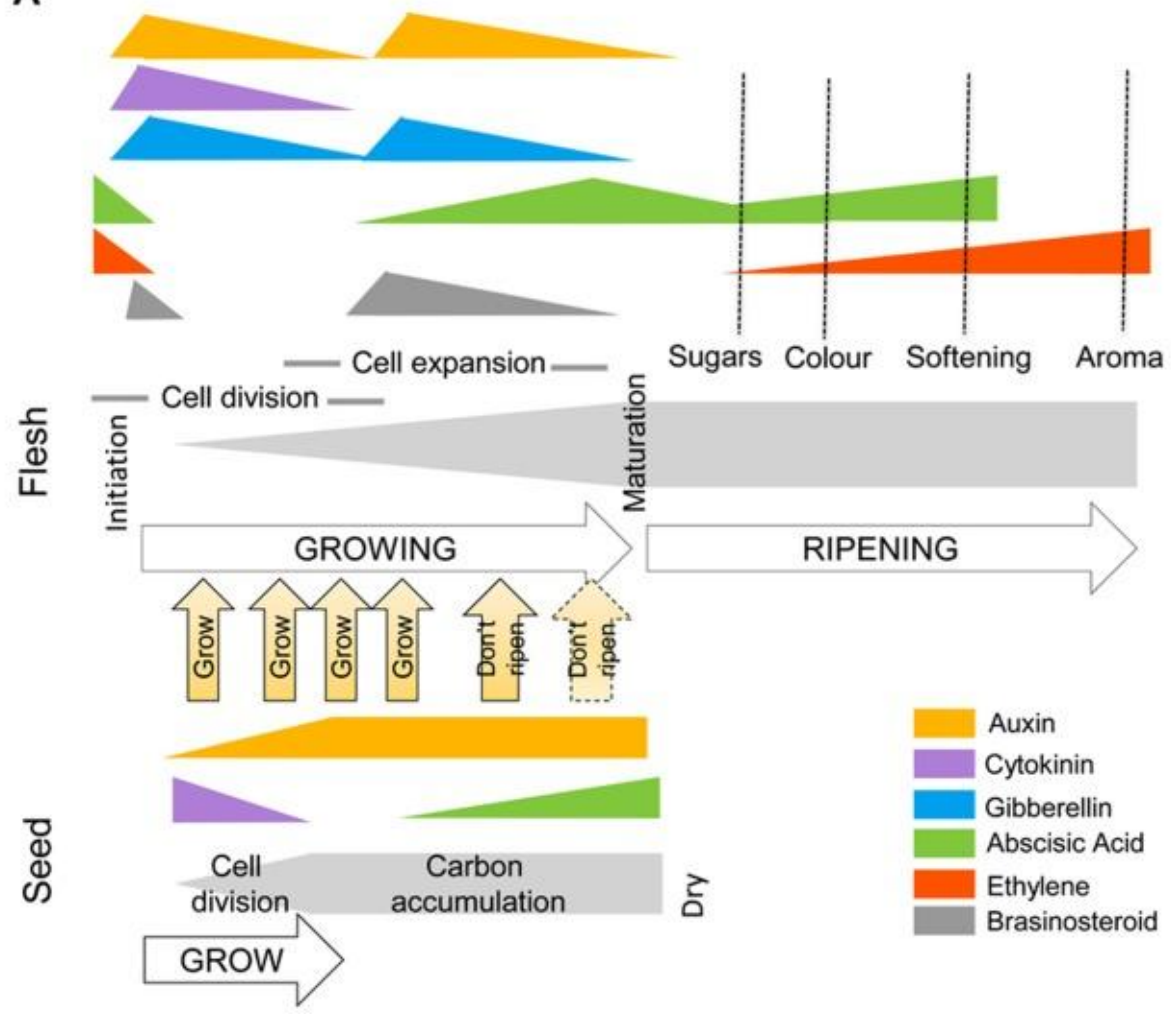

Fig.5 Hormonal regulation of fruit development (Mc Atee et al., 2013)

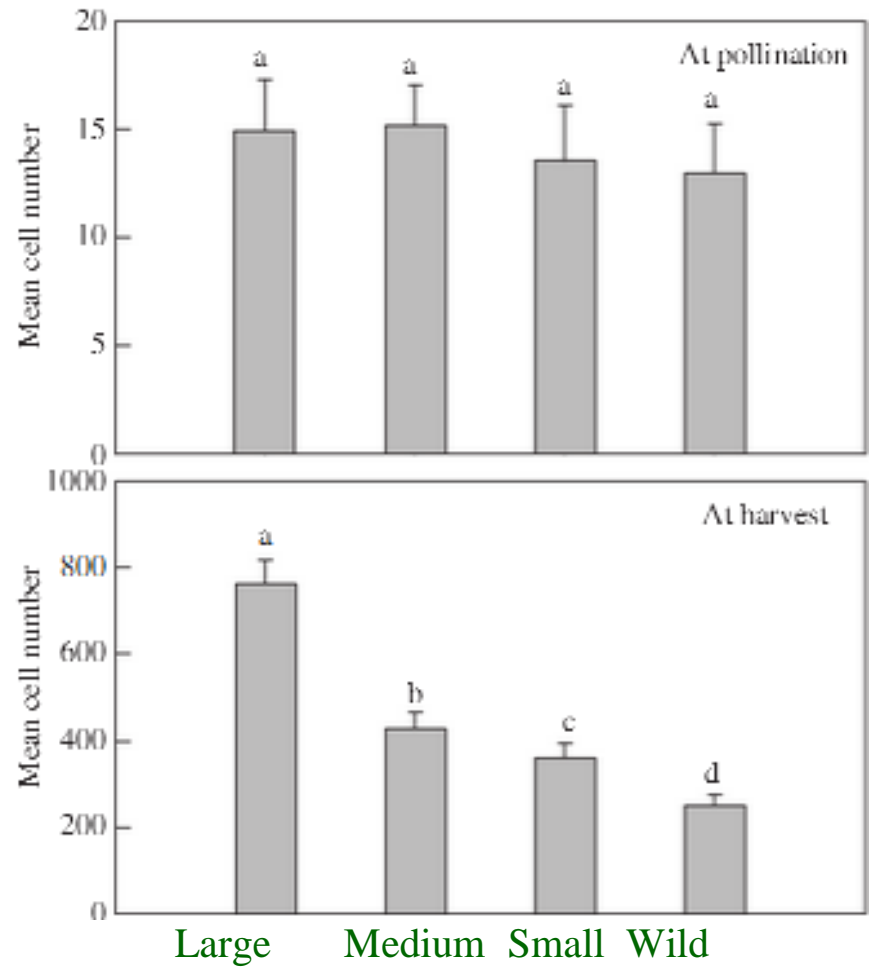

Fig.6 Cell number at pollination and harvest of different Pyrus pyrifolia cultivars 
Int.J.Curr.Microbiol.App.Sci (2020) 9(6): 504-521

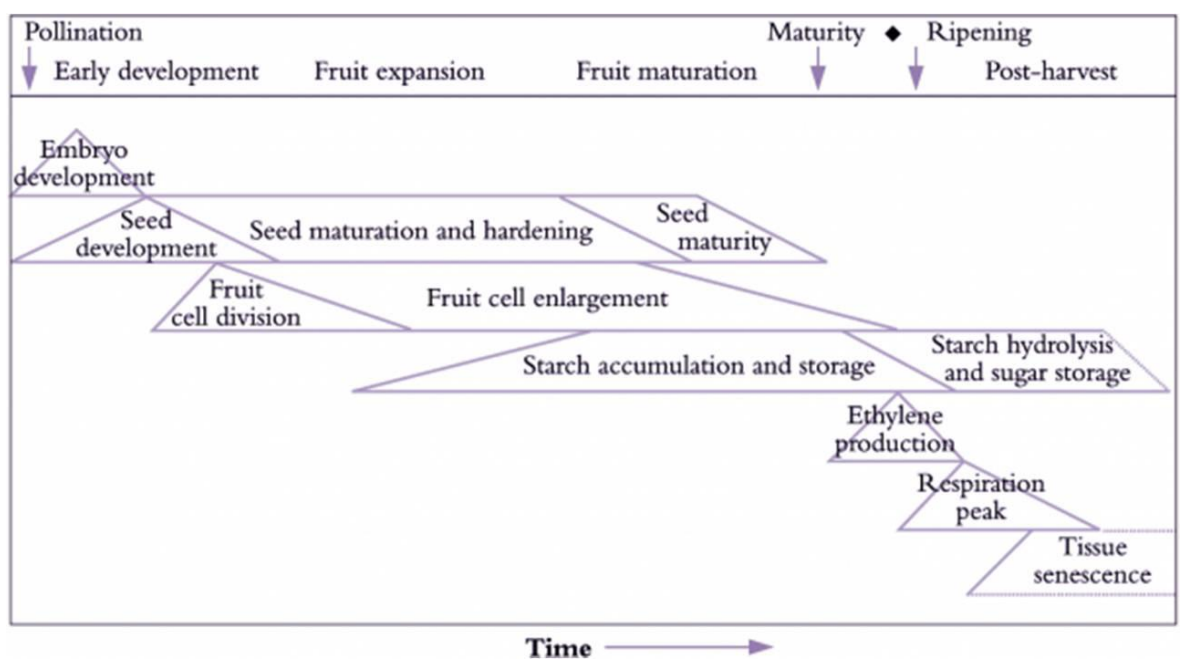

Fig.7 Fruit growth and seed development (Brummell, 2013)

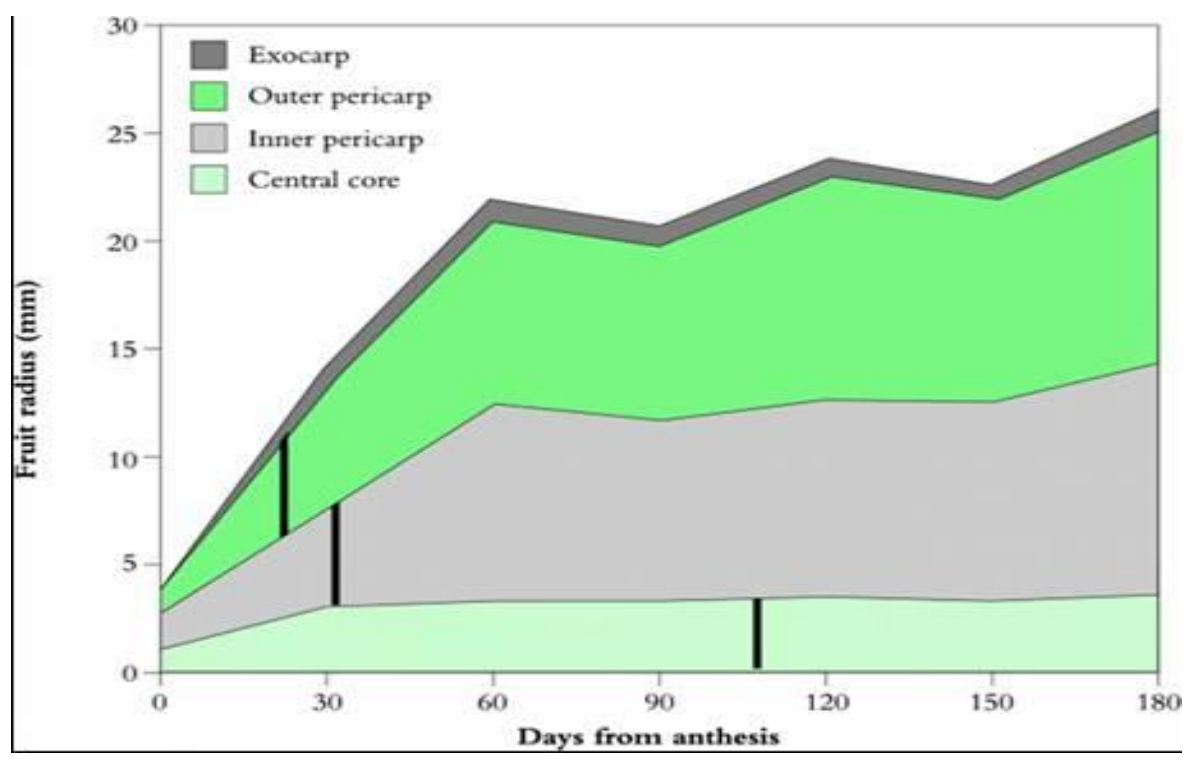

Fig.8 Fruit development in Kiwi fruit (Brummell, 2013)

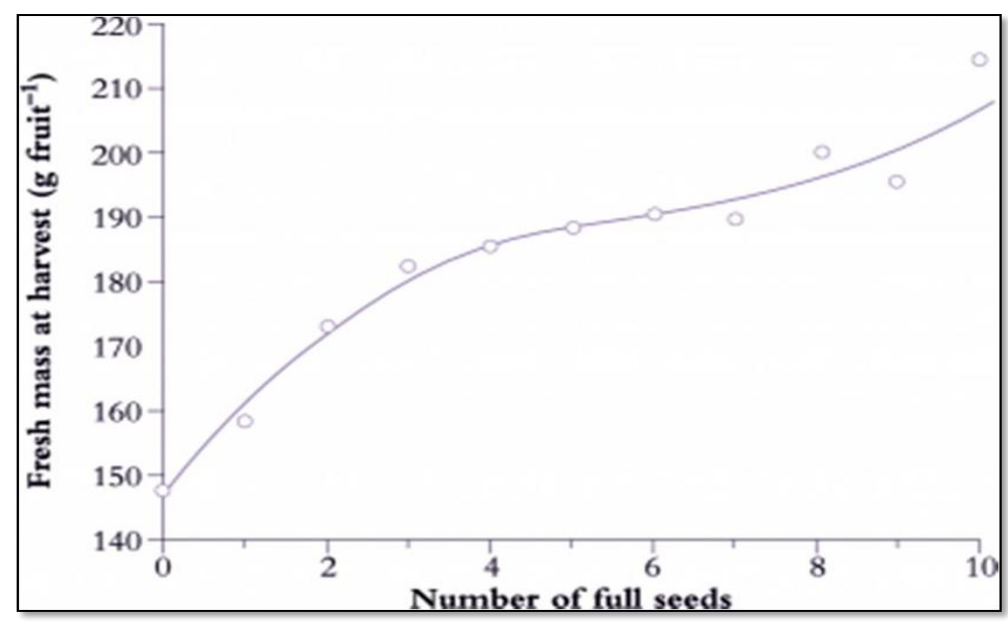

Fig.9 Fruit size in Braeburn apple in relation to seed (Brummell, 2013) 

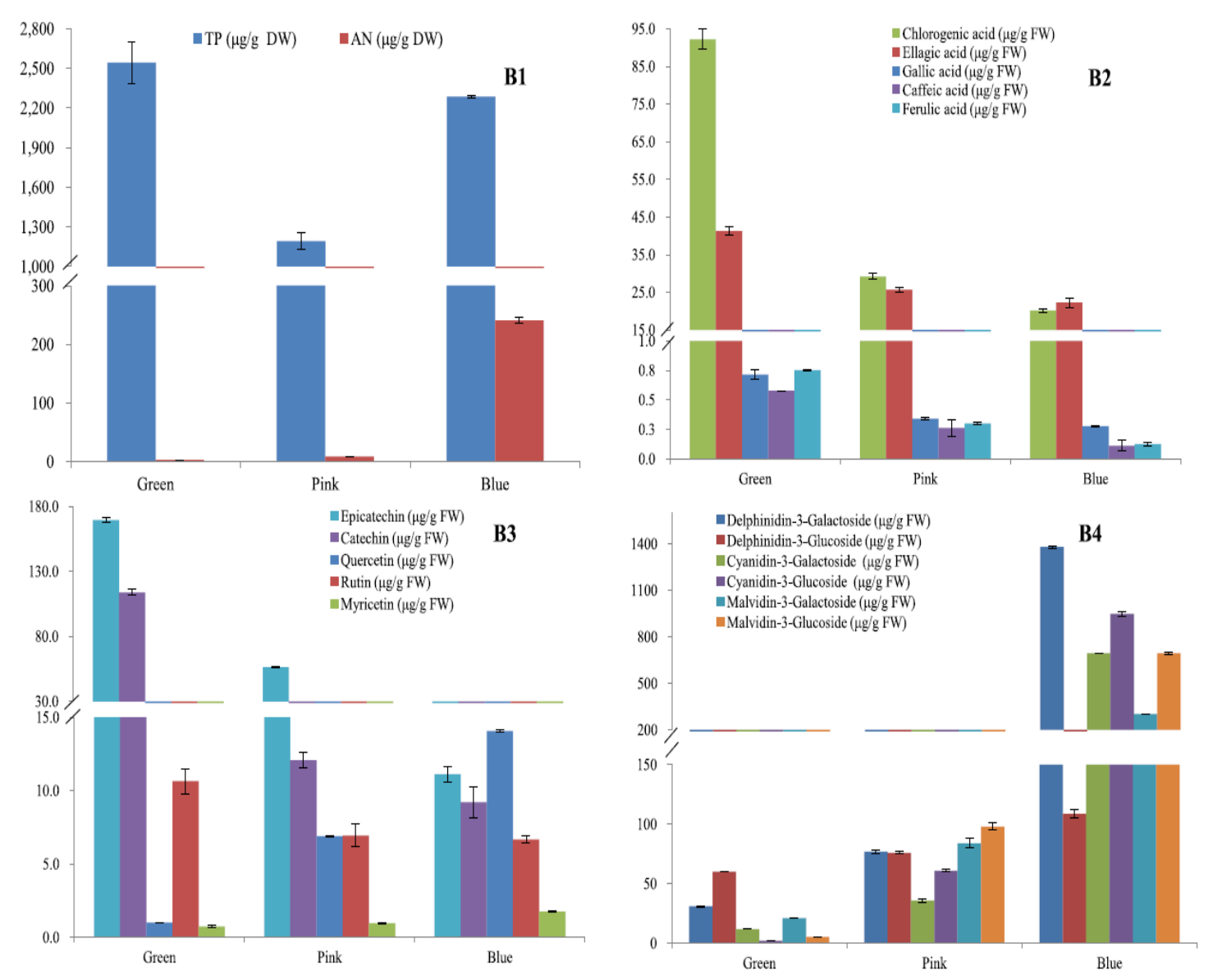

Fig.10 Dynamic changes of (B1) total phenolic (TP) and total anthocyanin (AN), (B2) phenolic acid, (B3) flavonols and flavanols, and (B4) anthocyanins during blueberry fruit maturation from green, to pink and to blue phases

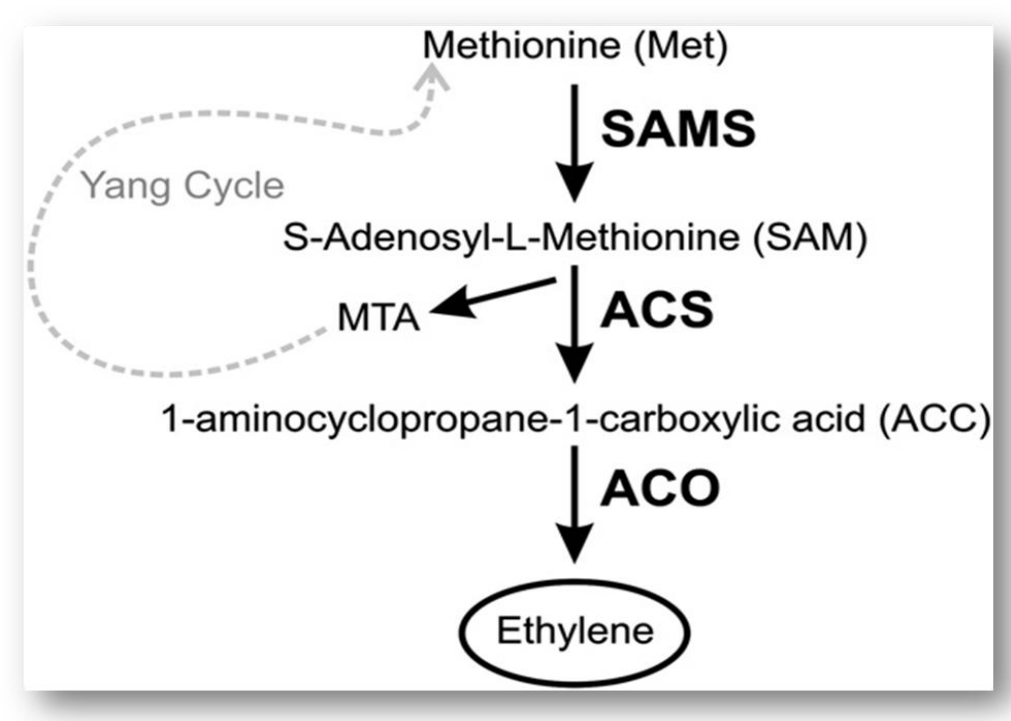

Fig.11 Ethylene biosynthesis in higher plants (Perotti et al., 2014) 


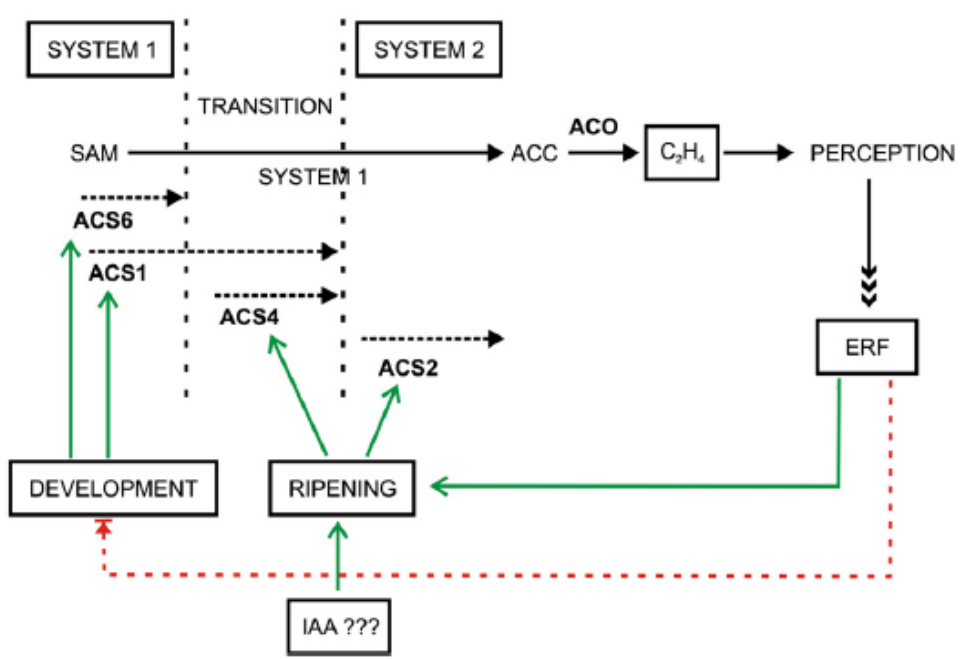

Fig.12 Regulation of ACS gene expression (Perotti et al., 2014)

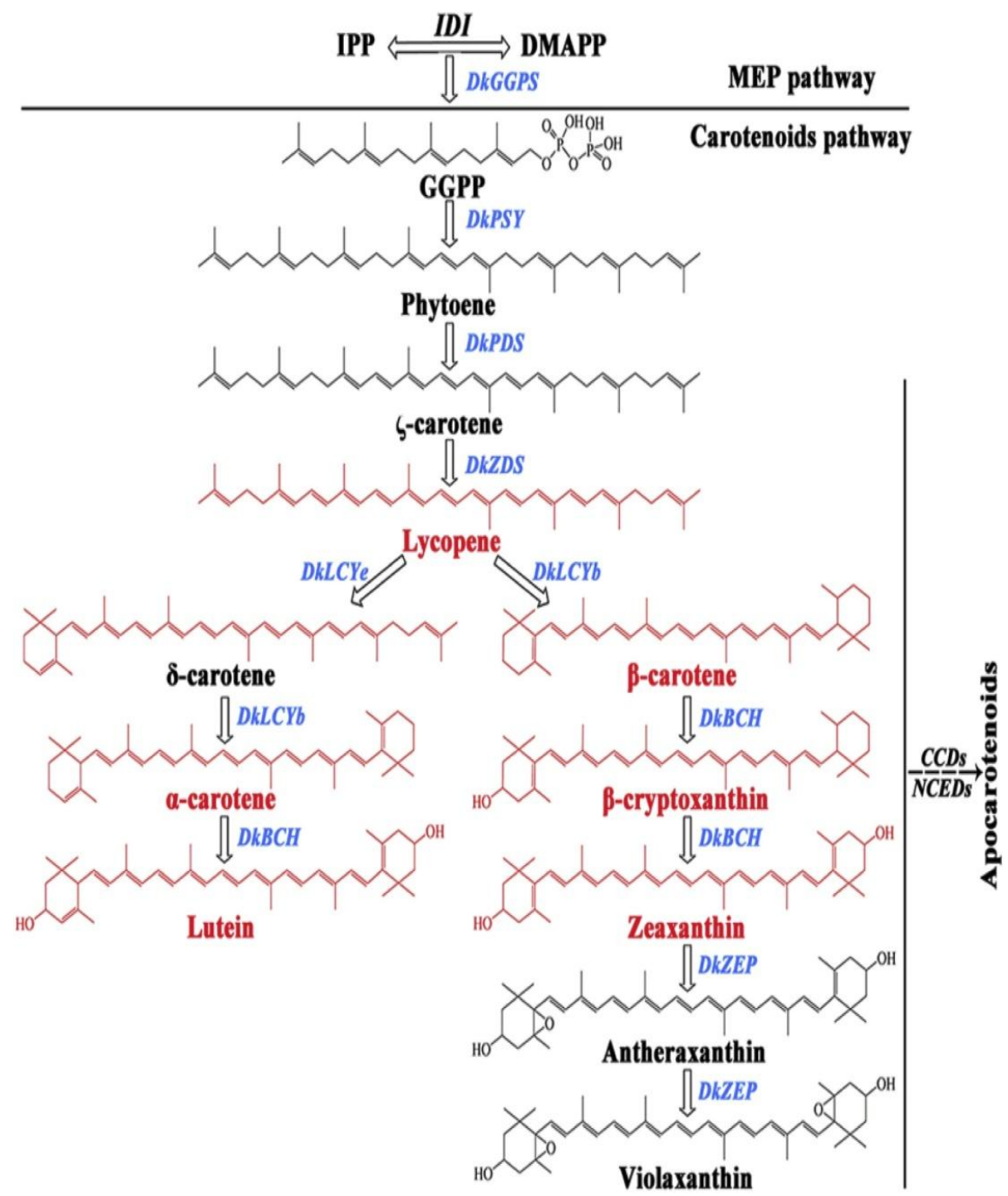

Fig.13 Carotenoid biosynthetic pathway 


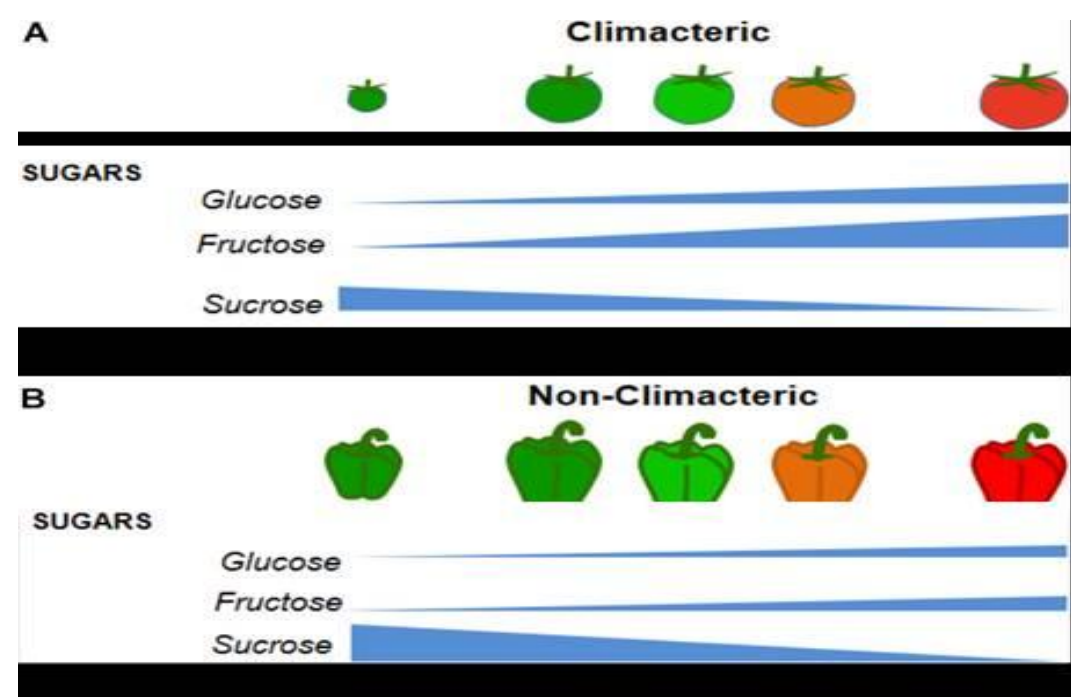

Fig.14 Status of sugars during ripening

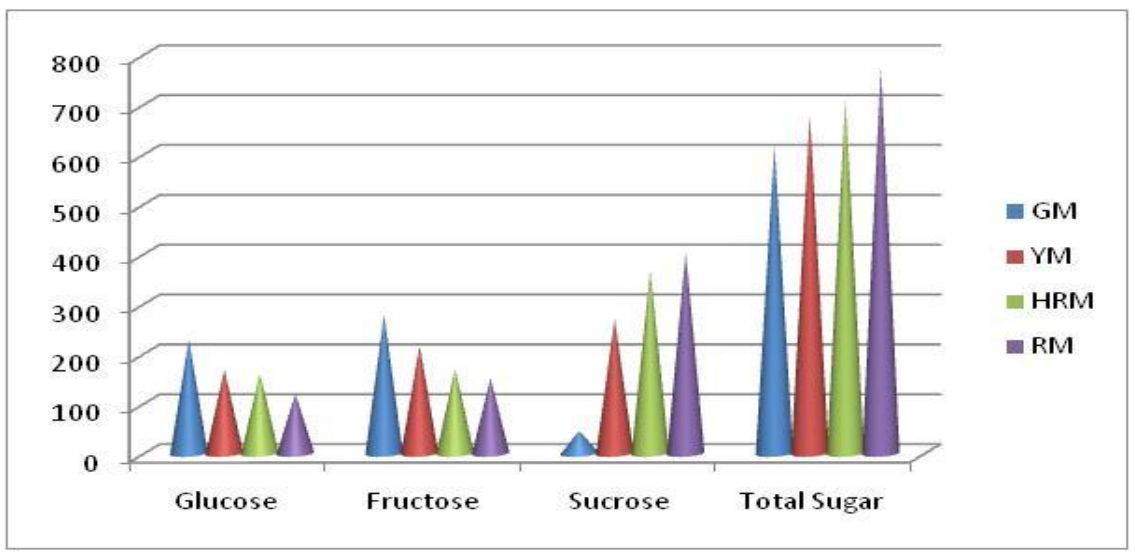

Fig.15 Status of sugars at ripening stages of jujube

A

\section{Climacteric}

ORGANIC ACIDS
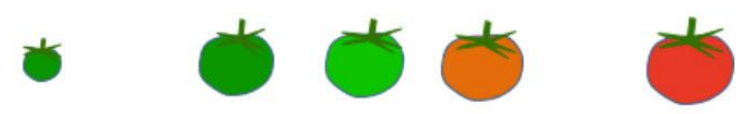

Citrate

Fumarate

Malate

B

Non-Climacteric

ORGANIC ACIDS

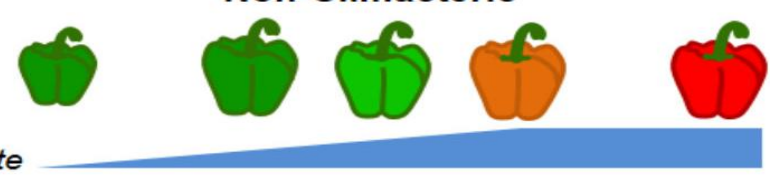

Fumarate

Malate

Fig.16 Status of organic acids during ripening 


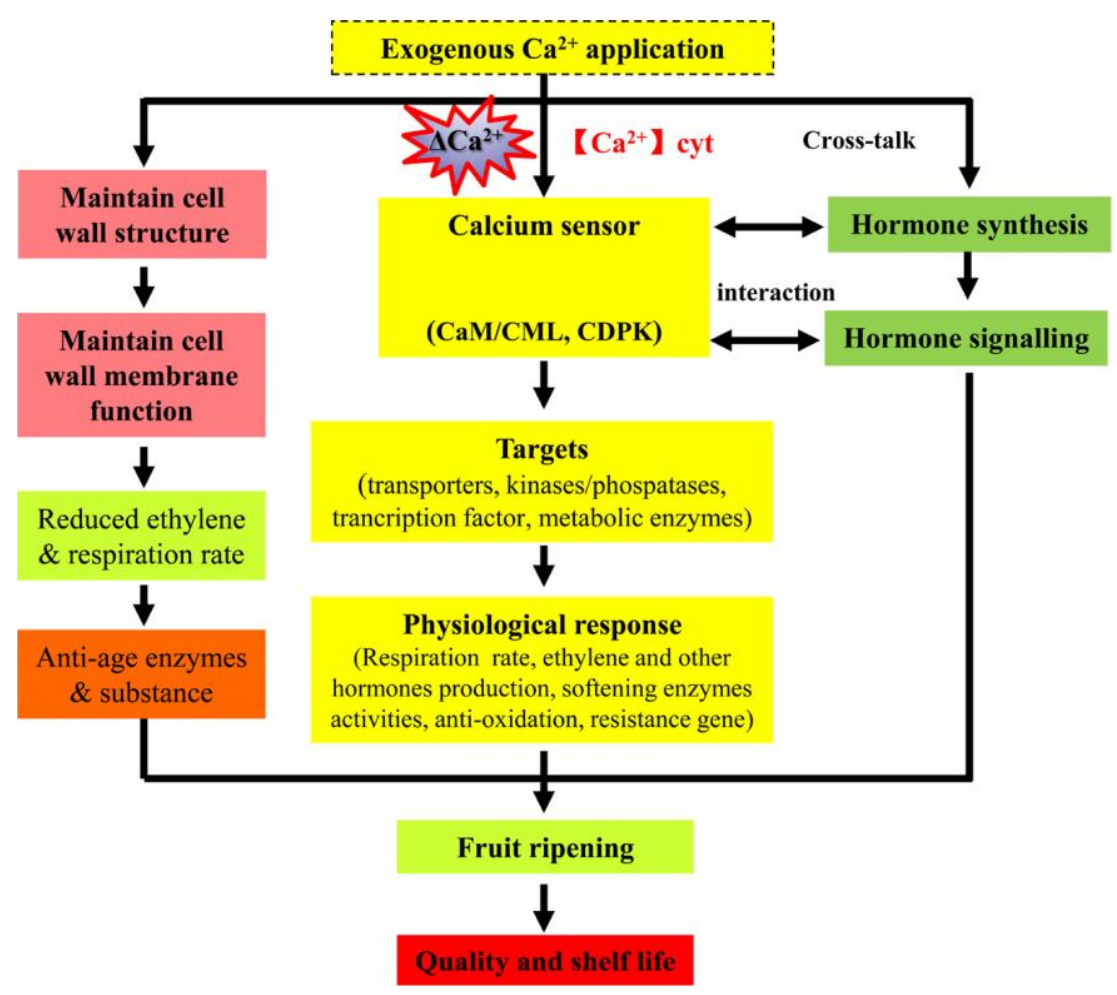

Fig.17 Model showing role of calcium in ripening Gao et al., (2019)

The physiology of fruit development is composed of a set of complex processes. Lots of variations were noticed in the fruit development of various species. Therefore, further studies are required on physiology of fruit development. Works on the developmental physiology of indigenous fruits of Assam and North East may be taken up.

\section{References}

Batista-Silva, W., Nascimento, V. L., Medeiros, D. B., Nunes-Nesi, A., Ribeiro, D. M., Zsögön, A. and Araújo, W. L. (2018). Modifications in Organic Acid Profiles During Fruit Development and Ripening: Correlation or Causation? Front. Plant Sci. 9: 1689.

Beauvoit, B., Belouah, I., Bertin, N., Cakpo, C. B., Colombié, S. and Dai, Z. (2018). Putting primary metabolism into perspective to obtain better fruits. Ann.
Bot. 122: $1-21$.

Beigi, T. M., Ngadi, M. O., Holman, D. B. and Chénier, M. R. (2015) Pectin Methylesterases: A Review. $J$. Bioprocess Biotech. 5: 228.c

Brummell, D. A. (2006). Cell wall disassembly in ripening fruit. Funct. Plant Biol. 33: 103 - 119.

Brummell, D. A. (2013). Chapter 11 - Fruit growth, ripening and post-harvest physiology. In: Plant in Action. Plant and Food Research, Palmerston North, Auckland.

Bustamante, C. \& Civello, P. and Martínez, G. (2009). Cloning of the promoter region of $\beta$-xylosidase (FaXyl1) gene and effect of plant growth regulators on the expression of FaXyl1 in strawberry fruit. Plant Sci. 177: 49 - 56.

Chea, S., Yu, D. J., Park, J., Oh, H. D., Chung, S. W. and Lee, H. J. (2019). Fruit softening correlates with enzymatic and compositional changes in 
fruit cell wall during ripening in 'Bluecrop' highbush blueberries. Hort. Sci. 245: 163 - 170.

Defilippi, B., Manriquez, D., Luengwilai, K. and González-Agüero, M. (2009). Aroma Volatiles: Biosynthesis and Mechanisms of Modulation during Fruit Ripening. Advances Bot. Res. 50: 1 37.

Ferrándiz, C., Liljegren, S. J. and Yanofsky, M.F. (2000). Negative regulation of the SHATTERPROOF genes by FRUITFULL during Arabidopsis fruit development. Sci. 289: 436 - 438.

Gao, Q., Xiong, T., Li, X., Chen, W. and Zhu, X (2019). Calcium and calcium sensors in fruit development and ripening. Sci. Hort. 253: 412 - 421.

Girin, T., Paicu, T., Stephenson, P., Fuentes, S., Korner, E., O'Brien, M., Sorefan, K., Wood, T. A., Balanza, V. and Ferrandiz, C. (2011). INDEHISCENT and SPATULA interact to specify carpel and valve margin tissue and thus promote seed dispersal in Arabidopsis. Plant Cell. 23: 3641 - 3653.

Goulao, L. F., Santos, J., de Sousa, I. and Oliveira, C. M. (2007). Patterns of enzymatic activity of cell wallmodifying enzymes during growth and ripening of apples. Postharvest Biol. Technol. 43: $307-318$.

Joldersma, D. and Liu, Z. (2018). The making of virgin fruit: the molecular and genetic basis of parthenocarpy. J. Exp. Bot. 69: 955 - 962.

Li, X., Jin, L., Pan, X., Yang, L. and Guo, W. (2019). Proteins expression and metabolite profile insight into phenolic biosynthesis during highbush blueberry fruit maturation. Food Chem. 290: 216 $-228$.

Liebminger, E., Hüttner, S., Vavra, U., Fischl, R., Schoberer, J. and Grass, J. (2009). Class I alpha-mannosidases are required for $\mathrm{N}$-glycan processing and root development in Arabidopsis thaliana. Plant Cell. 21: 3850 - 3867.

Liljegren, S. J., Ditta, G. S., Eshed, Y., Savidge, B., Bowman, J. L. and Yanofsky, M.F. (2000). SHATTERPROOF MADS-box genes control seed dispersal in Arabidopsis. Nat. 404: 766 - 770.

Mc Atee, P., Karim, S., Schaffer, R. and David, K. (2013). A dynamic interplay between phytohormones is required for fruit development, maturation, and ripening. Front Plant Sci. 4: 79.

Nitsch, J. (1952). Plant hormones in the development of fruit. Q. Rev. Biol. 27: $33-57$.

Pandit, S., Kulkarni, R., Chidley, H., Giri, A., Pujari, K., Köllner, T., Degenhardt, J., Gershenzon, J. and Gupta, V. (2009). Changes in volatile composition during fruit development and ripening of 'Alphonso' mango. J. Sci. Food Agri. 89: 2071 - 2081.

Perotti, V. E., Moreno, A. S. and Podestá, F. E. (2014). Physiological aspects of fruit ripening: The mitochondrial connection. Mitochondrion. 17: $1-6$.

Qi, Y., Liu, X., Zhang, Q., Wu, H., Yan, D., Liu, Y., Zhu, X., Ren, X. and Yang, Y. (2019). Carotenoid accumulation and gene expression in fruit skins of three differently colored persimmon cultivars during fruit growth and ripening. Sci. Hort. 248: 282 - 290.

Ramalho, R. R. F., Barbosa, J. M. G., Ferri, P. H. and Santos, S. C. (2019). Variability of polyphenols and volatiles during fruit development of three pitanga (Eugenia uniflora L.) biotypes. Food Res. Int. 119: $850-858$.

Roeder, A. H. K., Ferrándiz, C. and Yanofsky, M. F. (2003). The role of the REPLUM-LESS homeodomain protein in patterning the Arabidopsis fruit. Curr. Bio. 13: 1630 - 1635.

Ruan, Y. L., Patrick, J. W., Bouzayen, M., 
Osorio, S. and Fernie, A. R. (2012). Molecular regulation of seed and fruit set. Trends Plant Sci. 17: 1360-1385.

Song, J., Bia, J., Chen, Q., Wu, X., Lyu, Y. and Meng, X. (2019). Assessment of sugar content, fatty acids, free amino acids, and volatile profiles in jujube fruits at different ripening stages. Food Chem. 270: 344 - 352.

Xiao, Y., Kuang, J., Qi, X., Ye, Y., Wu, Z., Chen, J. and Lu, W. (2018). A comprehensive investigation of starch degradation process and identification of a transcriptional activator MabHLH6 during banana fruit ripening. Plant Biotechnol. J. 16(1): 151 - 164.

Yang, Y. N., Zheng, F. P., Yu, A. N. and Sun, B. G. (2019). Changes of the free and bound volatile compounds in Rubus corchorifolius L. f. fruit during ripening. Food Chem. 287: $232-240$.

Zhang, C., Kenji, T., Shiping, W., Fumio, T., Akira, Y. and Kazuhiro, M. (2006). The Impact of Cell Division and Cell Enlargement on the Evolution of Fruit Size in Pyrus pyrifolia. Annals Bot. 98: $537-543$.

\section{How to cite this article:}

Bhaskarjyoti Sarma, Kaushik Das and Sarat Sekhar Bora. 2020. Physiology of Fruit Development. Int.J.Curr.Microbiol.App.Sci. 9(06): 504-521. doi: https://doi.org/10.20546/ijcmas.2020.906.066 